\title{
Gene replacement in cyanobacteria mediated by a dominant streptomycin-sensitive rps 12 gene that allows selection of mutants free from drug resistance markers
}

\author{
Masayoshi Matsuoka, Kazutaka Takahama and Takahira Ogawa
}

Department of Applied Microbial Technology, Sojo University, Ikeda 4-22-1, Kumamoto 860-0082, Japan

\author{
Author for correspondence: Masayoshi Matsuoka. Tel: +8196326 3111. Fax: +81963231330. \\ e-mail:matsuoka@bio.sojo-u.ac.jp
}

Chromosomal gene replacement in cyanobacteria often relies upon the availability of drug resistance markers, and thus multiple replacements have been restricted. Here, a versatile gene replacement system without this restriction is reported in a unicellular cyanobacterium, Synechococcus sp. PCC 7942. The system is based upon the dominance of a streptomycin-sensitive rps12 gene encoding a ribosomal $\mathrm{S} 12$ protein over a streptomycin-resistant rps12-R43 allele with a Lys-43 $\rightarrow$ Arg substitution. To demonstrate the utility of this method, a cassette consisting of the wild-type rps12 gene and a kan gene conferring kanamycin resistance was integrated into the rps12-R43 mutant at the psbAl locus encoding photosystem II D1 protein, resulting in streptomycinsensitive merodiploids. Despite spontaneous gene conversion in these merodiploids to produce streptomycin-resistant progeny at frequencies ranging from $1 \times 10^{-5}$ to $5 \times 10^{-5}$, homologous recombination could be induced by transforming the merodiploids with template plasmids carrying psbAl 5' and $3^{\prime}$ non-coding sequences flanking the D1 coding sequence, which was then replaced by either the gfp ORF for a green fluorescent protein or a precise deletion. Depending on the replication ability of the template plasmids, at most 3-16\% of streptomycin-resistant progeny of the merodiploids after transformation were homogenote recombinants with concomitant loss of the kan gene, even in these polyploid cyanobacteria. The rps12-mediated gene replacement thus makes it possible to construct mutants free from drug resistance markers and opens a way to create cyanobacterial strains bearing an unlimited number of gene replacements.

Keywords: homologous recombination, Synechococcus, gene conversion, merodiploid, psbAI

\section{INTRODUCTION}

Cyanobacteria occupy particular niches in the hydrosphere and adapt to varying environments. They carry out oxygenic photosynthesis similar to that operating in green plant chloroplasts, while the simple genomic organization and ease of genetic manipulation of these micro-organisms attract in-depth biochemical and genetic studies of as yet unsolved biological processes.

Abbreviations: $\mathrm{Ap}^{\mathrm{r}}$, ampicillin-resistant; $\mathrm{Cm}^{\mathrm{r}}$, chloramphenicol-resistant $\mathrm{Cm}^{\mathrm{s}}$, chloramphenicol-sensitive; $\mathrm{Km}^{\mathrm{r}}$, kanamycin-resistant; $\mathrm{Km}^{\mathrm{s}}$, kanamycinsensitive; Smr', streptomycin-resistant; Str', streptomycin-resistant (chromosomal); Str', streptomycin-sensitive (chromosomal).
Recently, cyanobacteria have been revealed as one of the best experimental models to investigate the structure and function relationships of membranous pigmentprotein complexes called photosystem I and photosystem II (for reviews, see Nixon \& Diner, 1994; and Pakrasi, 1995). To genetically analyse these multisubunit complexes, a versatile method is needed to replace any chromosomal genes with in-vitro-constructed mutant genes without limitation of the number of manipulatable targets.

Some cyanobacterial strains, such as Synechococcus sp. PCC 7942 and Synechocystis sp. PCC 6803, are naturally transformable with externally added DNAs, and both integrative and replicative transformation systems are 
available in these strains (Chauvat et al., 1986; Kuhlemeier et al., 1983; Williams, 1988). However, due to the fact that homologous recombination mediated by recA function is essential for cell viability in cyanobacteria (Murphy et al., 1990), recombinant plasmids containing any sequences homologous with their host chromosome are not stably maintained in cyanobacterial cells. Consequently, these homologous sequences are integrated with the aid of dominant drug resistance markers into non-essential sites of the chromosome conventionally termed platforms (Geerts et al., 1995) or neutral sites (Bustos \& Golden, 1992). Although this method works well, one of the drawbacks is that the dominant drug resistance marker, once integrated, cannot be eliminated from the genome, and thus a subsequent genetic manipulation in the same strain is limited by the availability of other drug resistance markers.

Another difficulty in manipulating cyanobacterial genes arises from their polyploidy; i.e. the multiple copies of genomic DNA in some strains (Binder \& Chisholm, 1990). It is therefore of great importance to have a selection scheme that allows one to obtain mutants carrying homogeneous mutant genes on every copy of genomic DNA. Such homogenote (or homoallelic) mutants are only available for genes that are not essential for growth; otherwise heterogenotes containing the mutant as well as wild-type genes are formed (e.g. Ghassemian \& Straus, 1996; Murphy et al., 1990). In this regard, a dominant drug-sensitive marker should be easier to eliminate from the chromosome after its integration since even a single copy of the marker would reduce the ability of the polyploid host to survive in the presence of the drug.

It is well known that the rpsL gene encoding an $\mathrm{S} 12$ subunit protein of the $30 \mathrm{~S}$ ribosome in Escherichia coli gives rise to strA mutations conferring the streptomycinresistant $\left(\mathrm{Str}^{\mathrm{r}}\right)$ phenotype (Funatsu \& Wittmann, 1972; Timms et al., 1992). When the mutant and wild-type alleles coexist in a cell, the resulting merodiploid shows a streptomycin-sensitive $\left(\mathrm{Str}^{\mathrm{S}}\right)$ phenotype; i.e. the $\operatorname{str} A$ mutation is recessive (Lederberg, 1951). The cloned $r p s L$ gene thus behaves as a dominant $\operatorname{Str}^{\mathrm{s}}$ marker and has been utilized in a variety of genetic methods, including enforced cloning of foreign DNAs (Dean, 1981; Hashimoto-Gotoh et al., 1993), a detection system for specific mutations (Gondo et al., 1996) and a gene replacement system in a recD mutant (Russell \& Dahlquist, 1989). These methods depend upon the logic that only when the rpsL gene is inactivated in an $r p s L / r p s L(\operatorname{str} A)$ merodiploid strain can the cells grow in the presence of streptomycin.

In this work, we have developed a methodology capable of introducing multiple gene replacements into the obligate photoautotrophic cyanobacterium Synechococcus sp. PCC 7942 based on the same strategy as the $r p s L$ system in E. coli. For this purpose, the photosystem II $p s b A I$ gene encoding the $\mathrm{D} 1$ protein was chosen as a target, since the presence of three $p s b A$ genes in this strain permitted us to inactivate only the $p s b A I$ gene without affecting photoautotrophic growth (Golden et al., 1986). We first demonstrated that an rps12 gene encoding an S12 ribosomal protein acts as a dominant $\mathrm{Str}^{\mathrm{S}}$ marker in this cyanobacterium. We then applied the cloned rps12 gene to systematically modify the $p s b A I$ ORF without leaving any externally incorporated drug resistance markers in the final mutants. This method is thus well suited for the construction of multiple gene replacements in cyanobacteria in order to analyse complex biological processes such as photosystems I and II.

\section{METHODS}

Strains and plasmids. Synechococcus sp. PCC 7942 R2-SPc, which had been cured of an indigenous plasmid, pUH24, and a shuttle vector plasmid, pUC303, carrying a streptomycinresistant $\left(\mathrm{Sm}^{\mathrm{r}}\right)$ gene and a chloramphenicol-resistant $\left(\mathrm{Cm}^{\mathrm{r}}\right)$ gene (Kuhlemeier et al., 1983) were obtained from Dr Y. Inoue, RIKEN, Japan. A plasmid, pEXE1, carrying the $5^{\prime}$ and $3^{\prime}$ non-coding sequences of the psbAI gene from Synechococcus sp. PCC 7942, was constructed previously (Sakai et al., 1997). Plasmids pUC18, carrying an ampicillin-resistant $\left(\mathrm{Ap}^{\mathrm{r}}\right)$ gene, and pUC4K, carrying a kanamycin-resistant $\left(\mathrm{Km}^{\mathrm{r}}\right)$ gene, were purchased from Pharmacia. A plasmid, pGFPuv, carrying the $g f p$ gene (UV version), encoding a green fluorescent protein was obtained from Clontech Laboratories. E. coli strain JM109 was used for routine cloning. E. coli GM33 $(d a m-3)$ was used for the preparation of plasmids without dam methylation. Plasmids and cyanobacterial strains constructed in this work are described in Table 1.

Culture conditions. Cells of Synechococcus sp. strain PCC 7942 R2-SPc and its derivatives (Table 1) were grown photoautotrophically in liquid BG-11 medium in an incubator equipped with fluorescent lamps under continuous illumination of $4.4 \times 10^{-4} \mathrm{~J} \mathrm{~cm}^{-2} \mathrm{~s}^{-1}$ at $28^{\circ} \mathrm{C}$. E. coli cells were grown in LB medium at $37^{\circ} \mathrm{C}$. Appropriate antibiotics were added at concentrations of $50 \mu \mathrm{g}$ kanamycin $\mathrm{ml}^{-1}, 10 \mu \mathrm{g}$ streptomycin $\mathrm{ml}^{-1}, 50 \mu \mathrm{g}$ ampicillin $\mathrm{ml}^{-1}$ or $10 \mu \mathrm{g}$ chloramphenicol $\mathrm{ml}^{-1}$. For plating the cells, media were solidified with $1.5 \%$ agar.

PCR and DNA manipulations. Standard methods (Sambrook et al., 1989) were applied for digestion of DNA by restriction enzymes and cloning of DNA fragments into plasmids. PCR and inverse PCR were performed as described by Saiki et al. (1987) and Triglia et al. (1988), respectively, with the GeneAmp PCR system 2400 (Perkin Elmer-Applied Biosystems) and the oligonucleotide primers listed in Table 2. AmpliTaq GOLD (Perkin Elmer-Applied Biosystems) was used for most of the amplifications of DNA fragments. PCR fragments to be cloned into plasmids were amplified with Vent DNA polymerase (New England BioLabs), purified with Wizard PCR Preps (Promega) and cloned into pUC18 (SureClone Ligation Kit; Pharmacia). Nucleotide sequences were determined with a 310 Genetic Analyzer and reagents for BigDye Terminator Cycle Sequencing (Perkin Elmer-Applied Biosystems), as recommended by the supplier.

Sequencing of the rps12 gene region. Two degenerate PCR primers (nos 1 and 2) were used to amplify a part (361 bp) of the rps12 ORF. Both the fragments amplified from PCC 7942 R2-SPc (wild-type) and TEV1002-1 (a spontaneous $\mathrm{Str}^{\mathrm{r}}$ mutant) strains were cloned into pUC18, and the nucleotide sequences were determined. Fragments containing sequences outside the rps12 ORF were obtained by inverse PCR using primers 3, 4, 5 and 6 after cutting the chromosomal DNA with 
Table 1. Plasmids and cyanobacterial strains used in this study

\begin{tabular}{|c|c|c|}
\hline $\begin{array}{l}\text { Plasmid or } \\
\text { strain }\end{array}$ & Description or genotype* & Reference or source \\
\hline \multicolumn{3}{|l|}{ Plasmids } \\
\hline pEXE1 & $\begin{array}{l}\text { A } 1.8 \mathrm{~kb} \text { fragment upstream of the } p s b A I \text { ORF and a } 0.5 \mathrm{~kb} \text { fragment downstream of } \\
\text { the } p s b A I \text { ORF were PCR-amplified and cloned into the BamHI site of pUC19. The } \\
\text { two fragments were joined with a NotI site which was adjacent to a BanIII site at } \\
\text { the } 5^{\prime} \text { terminus of the } p s b A I \text { ORF; Ap }{ }^{r}, p s b A I \Delta \mathrm{ORF}\end{array}$ & Sakai et al. (1997) \\
\hline pEXE2 & $\begin{array}{l}\text { A } 1.0 \mathrm{~kb} \text { efe gene ORF encoding Pseudomonas syringae ethylene-forming enzyme } \\
\text { was PCR-amplified and cloned into the BanIII/NotI sites of pEXE1 to produce a } \\
\text { precise replacement of } p s b A I \text { ORF with the } e f e \text { ORF. Ap }{ }^{\mathrm{r}} \text {, psbAI::efeORF }\end{array}$ & Sakai et al. (1997) \\
\hline pIEK2 & $\begin{array}{l}\text { A } 1.25 \mathrm{~kb} \text { fragment from pUC4K containing the kan gene was cut out with HincII, } \\
\text { ligated with Not linkers and cloned into the Not } \mathrm{I} \text { site of pEXE2. The } \\
\text { transcriptional direction of the kan gene was the same as that of the efe gene. Ap }{ }^{\mathrm{r}} \\
\mathrm{Km}^{\mathrm{r}} \text {, psbAI::efeORF-kan }\end{array}$ & $\begin{array}{l}\text { Our laboratory stock } \\
\text { (unpublished) }\end{array}$ \\
\hline pEXR10 & $\begin{array}{l}\text { A } 579 \mathrm{bp} \text { fragment containing the } r p s 12 \text { gene with its promoter sequence was } \\
\text { amplified by PCR using primers } 9 \text { and } 10 \text { with a } 5^{\prime} \text { BanIII extension and cloned into } \\
\text { the BanIII site of pEXE1. The transcriptional direction of the } r p s 12 \text { gene was the } \\
\text { same as that of the } p s b A I \text { promoter on the pEXE1 vector. Ap }{ }^{\mathrm{r}}, p s b A I:: r p s 12\end{array}$ & This study \\
\hline pEXR11 & $\begin{array}{l}\text { A } 1.25 \mathrm{~kb} k a n \text { gene fragment from pIEK2 was cloned into the NotI site of pEXR10. } \\
\text { The transcriptional direction of the kan gene was opposite to that of the } r p s 12 \\
\text { gene. Ap } \mathrm{Km}^{\mathrm{r}} \text {, psbAI::rps12-nak }\end{array}$ & This study \\
\hline pEXR12 & $\begin{array}{l}\text { A } 1.25 \mathrm{~kb} \text { kan gene fragment from pIEK2 was cloned into the NotI site of pEXR10. } \\
\text { The transcriptional direction of the kan gene was the same as that of the rps12 } \\
\text { gene. Ap }{ }^{\mathrm{r}} \mathrm{Km}^{\mathrm{r}} \text {, psbAI::rps12-kan }\end{array}$ & This study \\
\hline pEXR20 & $\begin{array}{l}\text { A } 375 \text { bp ORF for the rps } 12 \text { gene was PCR-amplified with BanIII and NotI linkers at } \\
\text { the } 5^{\prime} \text { and } 3^{\prime} \text { termini, respectively, using primers } 11 \text { and } 12 \text {. The fragment was } \\
\text { cloned into the BanIII/NotI sites of pEXE1 to produce a precise replacement of the } \\
\text { psbAI ORF with the rps } 12 \text { ORF. Ap }{ }^{\mathrm{r}} \text {, psbAI::rps12ORF }\end{array}$ & This study \\
\hline pEXR21 & $\begin{array}{l}\text { A } 1.25 \mathrm{~kb} \text { kan gene fragment from pIEK2 was inserted into the NotI site of pEXR20. } \\
\text { The transcriptional direction of the kan gene was the same as that of the rps12 } \\
\text { gene. Ap } \mathrm{Km}^{\mathrm{r}} \text {, psbAI::rps12ORF-kan }\end{array}$ & This study \\
\hline pEXGFP & $\begin{array}{l}\text { A } 717 \text { bp } g f p \text { gene ORF fragment was PCR-amplified from pGFPuv using primers } 15 \\
\text { and } 16 \text { and was cloned into the BanIII/NotI sites of pEXE1 to produce a precise } \\
\text { replacement of the } p s b A I \text { ORF by the } g f p \text { ORF. Ap }{ }^{\mathrm{r}}, p s b A I:: g f p \text { ORF }\end{array}$ & This study \\
\hline pEXGFPK & $\begin{array}{l}\text { A } 1.25 \mathrm{~kb} \text { kan gene fragment from pIEK2 was inserted into the NotI site of } \\
\text { pEXGFP. The transcriptional direction of the kan gene was opposite to that of the } \\
\text { gfp gene. Ap } \mathrm{Km}^{\mathrm{r}} \text {, psbAI::gfpORF-nak }\end{array}$ & This study \\
\hline pUC3032 & 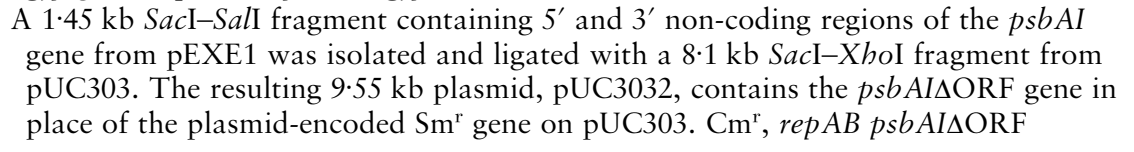 & This study \\
\hline \multicolumn{3}{|l|}{ Strains } \\
\hline TEV1002 & $\begin{array}{l}\text { Synechococcus sp. PCC } 7942 \text { R2-SPc whose } p s b A I \text { gene ORF was replaced with the } \\
\text { kan gene in the opposite orientation. The kan gene was flanked on both sides by } \chi \\
\text { and RS, which represent the E. coli chi site and the recognition site for site-specific } \\
\text { endonuclease I-TevI, respectively. psbAI:: } \chi \text { RS-nak-RS } \chi\end{array}$ & $\begin{array}{l}\text { Our laboratory stock } \\
\text { (unpublished) }\end{array}$ \\
\hline TEV1002-1 & A spontaneous $\operatorname{Str}^{r}$ mutant of TEV1002. psbAI:: $\chi \mathrm{RS}-n a k-\mathrm{RS} \chi$ rps12-R43 & This study \\
\hline GRPS1 & $\begin{array}{l}\text { A derivative of Synechococcus sp. PCC } 7942 \text { R2-SPc which received a PCR-generated } \\
\text { rps12-R43 gene fragment from TEV1002-1 and exhibited streptomycin resistance. } \\
\text { rps12-R43 }\end{array}$ & This study \\
\hline GRPS11 & $\begin{array}{l}\text { A derivative of GRPS1 in which the } p s b A I \text { gene was replaced by the sequence from } \\
\text { pEXR11. } r p s 12-R 43 p s b A I:: r p s 12-n a k\end{array}$ & This study \\
\hline GRPS12 & $\begin{array}{l}\text { A derivative of GRPS1 in which the } p s b A I \text { gene was replaced by the sequence from } \\
\text { pEXR12. rps12-R43 psbAI::rps12-kan }\end{array}$ & This study \\
\hline GRPS21 & $\begin{array}{l}\text { A derivative of GRPS1 in which the psbAI gene was replaced by the sequence from } \\
\text { pEXR21. rps12-R43 psbAI::rps12ORF-kan }\end{array}$ & This study \\
\hline GLC1 & $\begin{array}{l}\text { A Km } \mathrm{Km}^{\mathrm{r}} \text { transformant of PCC } 7942 \text { R2-SPc which received a copy of } p s b A I:: g f p \text { ORF- } \\
\text { nak from pEXGFPK. psbAI::gfpORF-nak }\end{array}$ & This study \\
\hline
\end{tabular}

*nak represents a kan gene inserted in the opposite transcriptional direction to that of the upstream gene. 
Table 2. Sequences of oligodeoxynucleotides used for PCR primers

\begin{tabular}{|c|c|c|c|}
\hline No. & Mer & Base sequence* & Target sequence $\dagger$ \\
\hline 1 & 26 & ATGCCAACTATCCAGCARYTNATHCG & rps12 $\mathrm{N}$ terminus (sense) \\
\hline 2 & 24 & GTTTGGTGCCGTATTTNGANCGNC & rps12 C terminus (antisense) \\
\hline 3 & 23 & GGTCAAAGACCTACCCGGTGTGC & rps12 C terminus (sense) \\
\hline 4 & 22 & TCGTGGTGTAGACGCGAGTGCA & rps12 $\mathrm{N}$ terminus (antisense) \\
\hline 5 & 23 & GCAGTTGACCTTGCTCGTTCCAG & rps12 3' non-coding (sense) \\
\hline 6 & 22 & TTCGCGTTCGTCGCGAATCAGC & rps12 $\mathrm{N}$ terminus (antisense) \\
\hline 7 & 24 & GTCTTTTCCAAGAGCAGCCGAACC & rps12 5' non-coding (sense) \\
\hline 8 & 23 & TGGAACGAGCAAGGTCAACTGCC & rps12 3' non-coding (antisense) \\
\hline 9 & 32 & CCCATCGATGTTCCAGAGAGGCTACCTGGGGC & rps12 5' non-coding (sense) \\
\hline 10 & 32 & CCCATCGATTGGAACGAGCAAGGTCAACTGCC & rps12 3' non-coding (antisense) \\
\hline 11 & 35 & CCCATCGATATGCCTACAATCCAGCAGCTGATTCG & rps12 $\mathrm{N}$ terminus (sense) \\
\hline 12 & 32 & TTTGCGGCيCGCCTAGGCCTTCGGACGCTTCGC & rps12 C terminus (antisense) \\
\hline 13 & 24 & GAGCACTGTAGCCTTGGGCGATCG & psbAI 5' non-coding (sense) \\
\hline 14 & 25 & GGGCAATGCGTTGTTGCAGTACCTC & psbAI 3' non-coding (antisense) \\
\hline 15 & 40 & CCCATCGATATGAGTAAAGGAGAAGAACTTTTCACTGGAG & $g f p \mathrm{~N}$ terminus (sense) \\
\hline 16 & 38 & TTTGيGGGCCGCTTATTTGTAGAGCTCATCCATGCCATG & gfp C terminus (antisense) \\
\hline
\end{tabular}

$* \mathrm{~N}=\mathrm{A}, \mathrm{C}, \mathrm{G}$ or $\mathrm{T} ; \mathrm{R}=\mathrm{A}$ or $\mathrm{G} ; \mathrm{Y}=\mathrm{C}$ or $\mathrm{T} ; \mathrm{H}=\mathrm{A}, \mathrm{C}$ or $\mathrm{T}$; restriction sites used for cloning are denoted by solid underlining $($ BanIII) or dotted underlining (NotI).

† Sense and antisense denote the coding and non-coding strands, respectively.

PvuII and PstI to generate 1.4 and $3.5 \mathrm{~kb}$ DNA fragments, respectively, and religation. Inverse PCR fragments were directly sequenced using the same primers. A $491 \mathrm{bp}$ PCR fragment containing the rps 12 gene with 35 bp $5^{\prime}$ and 81 bp 3' non-coding regions was prepared by using primers 7 and 8 , whereas a 375 bp PCR fragment containing only the rps12 ORF was amplified with primers 11 and 12 .

Electroporation. Cyanobacterial cells were grown in BG-11 medium supplemented with appropriate antibiotics to a density of $10^{8}$ cells $\mathrm{ml}^{-1}$. The cells in $1.0 \mathrm{ml}$ culture were collected by centrifugation in $1.5 \mathrm{ml}$ sterile centrifuge tubes at $13000 \mathrm{~g}$ for $5 \mathrm{~min}$ at $4{ }^{\circ} \mathrm{C}$, and the supernatant was discarded. The cells were suspended in $1.0 \mathrm{ml} \mathrm{SH}$ buffer $(272 \mathrm{mM}$ sucrose, $8 \mathrm{mM}$ HEPES, pH 7.4), centrifuged, and the supernatant was removed. The cells were washed as above with $0 \cdot 2 \mathrm{ml} \mathrm{SH}$ buffer, suspended in $20 \mu \mathrm{l} 2 \times \mathrm{SH}$ buffer and cooled on ice. A $20 \mu \mathrm{l}$ aliquot of cell suspension was transferred to a cuvette of $0 \cdot 1 \mathrm{~cm}$ path length (Bio-Rad), and necessary DNA solutions and sterile water was added to a final liquid volume of $40 \mu \mathrm{l}$. The cuvette was capped and cooled on ice before electroporation at $900 \mathrm{~V}, 129 \Omega, 50 \mu \mathrm{F}$, using an Electro Cell Manipulator (model 600M; BTX). Immediately after electroporation, $1.0 \mathrm{ml} \mathrm{BG}-11$ medium was added into the cuvette, and the cells were suspended with a pipette, transferred into a sterile centrifuge tube and kept for $10 \mathrm{~min}$ on ice. The cells were then collected by centrifugation at $13000 \mathrm{~g}$ for $1 \mathrm{~min}$ at $4{ }^{\circ} \mathrm{C}$, and the supernatant was discarded. The cells were again washed with $1.0 \mathrm{ml}$ of BG-11 medium, resuspended in $1.0 \mathrm{ml}$ BG-11 medium and transferred into an empty sterile glass test tube with a cotton plug. The tube was shaken on a reciprocal shaker at 100 r.p.m. in an illuminated incubator at $28^{\circ} \mathrm{C}$ overnight. Finally, the cells were spread onto BG-11 agar plates and incubated at $28{ }^{\circ} \mathrm{C}$ under light for up to 2 weeks.

Curing of plasmids. For curing of plasmids from cyanobacterial transformants, cells were cultivated photoautotrophically in BG-11 medium in the absence of the antibiotic to which the resistance had been conferred by the plasmid. When the $\mathrm{OD}_{730}$ of the culture exceeded $1 \cdot 0$, a portion of the culture was transferred into a tube containing fresh BG-11 medium, and the cultivation was repeated until cells had been propagated for 32 generations. The culture was then diluted and spread on BG-11 medium. The colonies formed were then replicated with nylon membrane (Hybond $\mathrm{N}+$; Amersham Pharmacia) onto BG-11 medium containing appropriate antibiotics. Cured strains that no longer grew in the presence of antibiotics made up $15-20 \%$ of the population after 32 generations.

Fluorescence microscopic observation. Cellular fluorescence was observed with a fluorescence microscope (Olympus OPTICAL model BX50 microscope; BX-FLA reflected light illuminator equipped with a mercury burner). Excitation was done at 360-370 nm, while 510-550 nm emission was observed through an absorption filter.

Southern blot analysis. Five to ten micrograms of chromosomal DNA were digested with restriction enzymes, electrophoresed on agarose gel and transferred onto a nylon membrane (Hybond $\mathrm{N}+$ ) by vacuum suction (VacuGene XL; Amersham Pharmacia). DNA probes were prepared by labelling with digoxigenin using a PCR Dig Labeling Mix (Roche Diagnostics). Hybridization of the membrane with a probe was carried out in a buffer containing $5 \times$ SSC $(75 \mathrm{mM}$ sodium citrate, $\mathrm{pH} 7 \cdot 0$, and $0.75 \mathrm{M} \mathrm{NaCl}$ ) at $62-65^{\circ} \mathrm{C}$ overnight. The hybridized membrane was treated with antidigoxigenin-alkaline phosphatase Fab fragments (Roche Diagnostics) and luminescent substrate (Lumi-Phos 530; Wako Pure Chemical Industries) as recommended by the manufacturer, and exposed to X-ray film (XAR; Kodak).

\section{RESULTS}

\section{Isolation and characterization of a streptomycin- resistant mutant}

As a prerequisite for streptomycin selection of gene replacements, a well-defined Str ${ }^{r}$ mutant is essential. Although the spontaneous frequency for occurrence of 
Table 3. Transformation of Synechococcus sp. GRPS1 with psbAl gene disruption plasmids

\begin{tabular}{|c|c|c|c|c|}
\hline $\begin{array}{l}\text { Plasmids (gene } \\
\text { on fragment)* }\end{array}$ & $\begin{array}{c}\text { Amount of } \\
\text { DNA used }(\mu \mathrm{g})\end{array}$ & $\begin{array}{l}\text { Number of } \mathrm{Km}^{\mathrm{r}} \\
\text { transformants }\end{array}$ & $\begin{array}{c}\text { Ratio of } \operatorname{Str}^{\mathrm{s}} / \mathrm{Str}^{\mathrm{r}} \\
\text { phenotypes } \dagger\end{array}$ & $\begin{array}{c}\text { Spontaneous gene } \\
\text { conversion frequency } \neq\end{array}$ \\
\hline \multirow{2}{*}{$\begin{array}{l}\mathrm{pEXR} 11 / \text { Bam HI } \\
(\text { psbAI::rps12-nak) }\end{array}$} & 6 & 475 & $3 / 1$ & ND \\
\hline & 3 & 1110 & $1 / 3$ & $4 \cdot 4 \times 10^{-5}($ GRPS11) \\
\hline \multirow{2}{*}{$\begin{array}{l}\mathrm{pEXR} 12 / \text { Bam HI } \\
(\text { psbAI::rps12-kan) }\end{array}$} & 6 & 321 & $3 / 1$ & ND (GRPS12) \\
\hline & 3 & 26 & $4 / 0$ & $2.5 \times 10^{-5}$ \\
\hline \multirow{4}{*}{$\begin{array}{l}\text { pEXR21/BamHI } \\
(\text { psbAI::rps12ORF-kan) }\end{array}$} & 8 & 60 & $4 / 0$ & $1.7 \times 10^{-5}(\mathrm{GRPS} 21)$ \\
\hline & 6 & 1 & $1 / 0$ & ND \\
\hline & 4 & 72 & $4 / 0$ & $1 \cdot 1 \times 10^{-5}$ \\
\hline & 2 & 80 & $4 / 0$ & $5 \cdot 4 \times 10^{-5}$ \\
\hline
\end{tabular}

*Plasmids were cut by BamHI and used for electroporation without further purifying the fragments.

† Streptomycin sensitivity/resistance is represented as the ratio of colony numbers tested; for example, a ratio of $3 / 1$ indicates that three transformants were $\operatorname{Str}^{\mathrm{s}}$ while one was $\operatorname{Str}^{\mathrm{r}}$.

$\neq$ Selected $\mathrm{Km}^{\mathrm{r}} \mathrm{Str}^{\mathrm{s}}$ transformants (including GRPS11, 12 and 21 as indicated in parentheses) were grown in BG-11 medium, and cells were plated onto BG-11 media containing either kanamycin or streptomycin to calculate the fraction of spontaneous gene conversion to produce Str ${ }^{\mathrm{r}}$ progeny. Values represent single measurements. ND, Not determined.

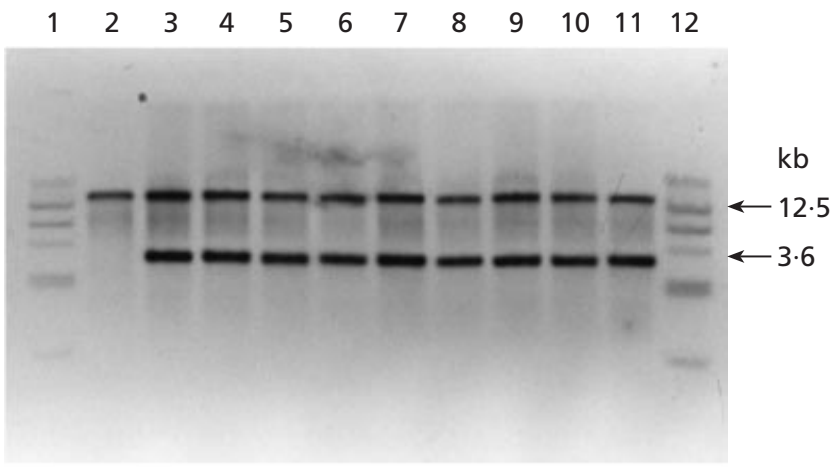

Fig. 1. Chromosomal status of rps12 merodiploids. Chromosomal DNAs from selected $\mathrm{Km}^{\mathrm{r}}$ transformants exhibiting $\mathrm{Str}^{\mathrm{S}}$ and $\mathrm{Str}^{\mathrm{r}}$ phenotypes were analysed by Southern hybridization using the rps12 ORF probe. Hybridization was performed in $5 \times \mathrm{SSC}$ at $62{ }^{\circ} \mathrm{C}$. Lanes $2-11$ contained $5 \mu \mathrm{g}$ chromosomal DNAs digested with HindIII. Samples in lanes 3-8 were from Str ${ }^{\mathrm{s}}$ transformants, whereas those in lanes 9-11 were from $\mathrm{Str}^{\mathrm{r}}$ transformants. Lanes: 1 and 12, digoxigenin-labelled, HindlII-cut $\lambda$ DNA marker; 2, GRPS1; 3, 4, 5, 9 and 10, transformants of GRPS1 obtained with pEXR11 carrying psbAl::rps12-nak insertion; 6, 7, 8 and 11, transformants obtained with pEXR12 carrying a psbAl::rps12-kan insertion. Since HindIII cuts the kan gene nearly symmetrically, a slight mobility difference between rps12-nak and rps12-kan fragments was not evident here. Sizes of hybridizing bands are indicated on the right.

Str ${ }^{\mathrm{r}}$ mutants in Synechococcus sp. PCC 7942 R2-SPc was less than $10^{-8}$, we found by chance a spontaneous $\operatorname{Str}^{\mathrm{r}}$ mutant from strain TEV1002 carrying the kan gene conferring kanamycin resistance at the psbAI locus (Table 1). The $\mathrm{Km}^{\mathrm{r}} \mathrm{Str}^{\mathrm{r}}$ mutant strain was designated TEV1002-1, and its rps12 gene encoding the S12 ribosomal protein was compared with the wild-type rps12 gene as described in Methods. A contiguous $1428 \mathrm{bp}$ nucleotide sequence including the rps12 gene and a part of the rps 7 gene downstream of the rps12 gene was determined, and found to be identical to the sequence (GenBank accession X17442) reported by Meng et al. (1989) in Synechococcus sp. PCC 6301, formerly called Anacystis nidulans. This result was not unexpected since PCC 7942 and PCC 6301 are nearly identical strains (Golden et al., 1989).

Within the regions sequenced, the only difference between the wild-type and the mutant rps12 genes is a single base transition from A to $G$ at position 128 of the ORF. The point mutation occurred at the second position of the 43rd codon, resulting in a replacement of a lysine (AAA) with an arginine (AGA) codon. Accordingly, the mutant allele was designated rps12-R43. We verified that the mutation in the rps12-R43 gene is the sole change determining the $\operatorname{Str}^{\mathrm{r}}$ phenotype of the mutant by transforming Synechococcus sp. PCC 7942 R2-SPc to streptomycin resistance with a PCR-generated 375 bp DNA fragment of the rps12-R43 ORF. An $\mathrm{Str}^{\mathrm{r}}$ transformant was obtained and was found by sequencing of its rps12 gene to have the same point mutation as the rps12-R43 allele. This strain was named GRPS1, and it was used as the standard rps12-R43 mutant. Using an rps12 probe, a single band was detected in genomic Southern hybridization with several restriction digests, indicating a single-copy rps12 gene (data not shown). 


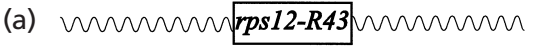

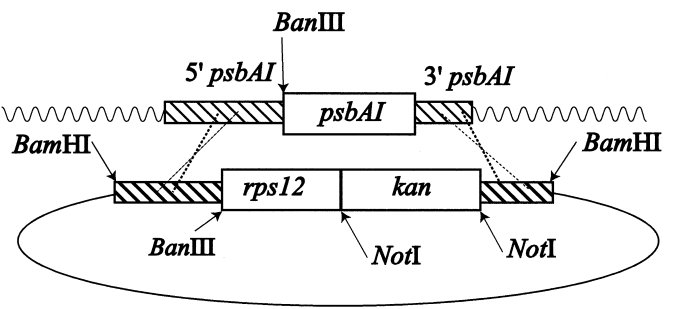

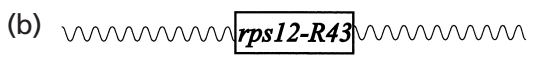

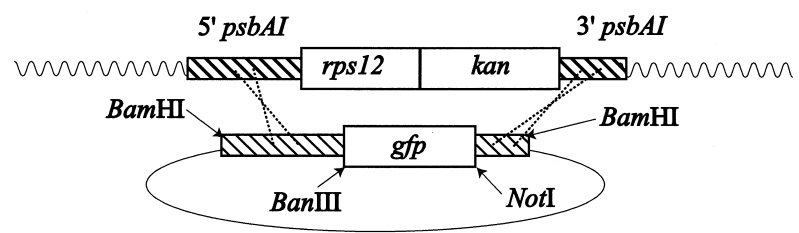

(c) иимиนrps12-R43

भun

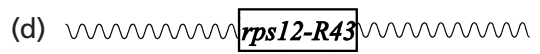

นиน

Fig. 2. Schematic representation of gene replacement utilizing the dominant rps12 gene. Chromosomal and plasmid DNAs are shown by wavy and ellipsoidal lines, respectively. Individual genes or ORFs are represented by rectangular boxes, whereas the psbAl $5^{\prime}$ and $3^{\prime}$ flanking non-coding sequences are represented by hatched boxes. Possible routes for recombination between homologous sequences are shown by dotted lines. Only relevant restriction sites are shown. (a) Top, Chromosomal state in a Str ${ }^{r}$ strain carrying the rps12-R43 allele; bottom, plasmid used to disrupt the psbAl gene by rps12 and kan genes. (b) Top, Chromosomal state in a $\mathrm{Str}^{\mathrm{s}} \mathrm{Km}^{\mathrm{r}}$ merodiploid strain carrying the rps12-R43 and psbAl::rps12-kan alleles; bottom, template plasmid carrying a gfp gene within the psbAl $5^{\prime}$ and $3^{\prime}$ flanking sequences. (c) Chromosomal state in a $\mathrm{Str}^{\mathrm{r}} \mathrm{Km}^{\mathrm{s}}$ recombinant after gene replacement at the psbAl locus. (d) Chromosomal state in a $\mathrm{Str}^{r} \mathrm{Km}^{r}$ merodiploid strain after gene conversion of the rps12 gene inserted at the psbAl locus into the rps12-R43 allele.

\section{Merodiploid analysis for the recessiveness of rps12-R43 allele}

We tested the dominance/recessiveness of the $r p s 12-R 43$ allele by constructing merodiploid strains in which a wild-type rps12 gene was inserted into a non-essential psbAI locus in the rps12-R43 background. For this purpose, pEXE1, carrying the psbAI 5' and 3' flanking sequences with a precise deletion of the D1 protein coding sequence, was used to clone the wild-type rps12 gene with its own promoter or the rps12 ORF fragment followed by the kan gene, generating the gene disruption plasmids pEXR11, pEXR12 and pEXR21 (Table 1). These plasmids were linearized by $B a m \mathrm{HI}$ digestion prior to transformation of strain GRPS1 to facilitate two-point homologous recombination (see Fig. 2a) rather than a single-point insertion of the whole plasmid into the $p s b A I$ locus.

The results presented in Table 3 show that $\mathrm{Km}^{\mathrm{r}}$ transformants of strain GRPS1 were $\operatorname{Str}^{\mathrm{s}}$ using pEXR21, while $\operatorname{Str}^{\mathrm{s}}$ and $\mathrm{Str}^{\mathrm{r}}$ phenotypes segregated among transformants using pEXR11 and pEXR12. The latter phenomenon could be explained by intrachromosomal recombination leading to gene conversion of the wildtype $r p s 12$ to the rps12-R43 allele because even $\mathrm{Km}^{\mathrm{r}} \mathrm{Str}^{\mathrm{S}}$ transformants spontaneously segregated $\operatorname{Str}^{r}$ progeny at frequencies of $1.1 \times 10^{-5}-5 \cdot 4 \times 10^{-5}$. In addition, Southern hybridization of both $\mathrm{Str}^{\mathrm{S}}$ and $\mathrm{Str}^{\mathrm{r}}$ transformants showed that they were in fact merodiploids, exhibiting two rps12 bands, the $3.6 \mathrm{~kb}$ HindIII fragment of which corresponds to the rps12 gene inserted at the psbAI locus (Fig. 1). We concluded that the $\operatorname{Str}^{\mathrm{r}}$ rps12$R 43$ allele is recessive to the $\operatorname{Str}^{\mathrm{S}}$ wild-type $r p s 12$ gene, and that the dominant $\operatorname{Str}^{\mathrm{S}}$ rps12 gene inserted at the psbAI locus is liable to be converted into the resistant allele spontaneously. This premise was confirmed by the direct sequencing of PCR fragments of the $p s b A I$ region, which showed that an $\operatorname{Str}^{r}$ merodiploid carried an $r p s 12-$ $R 43$ allele at the $p s b A I$ locus (data not shown).

\section{Gene replacement in rps12 merodiploids triggered by non-replicating template plasmids}

Since $r p s 12-R 43 / r p s 12$ merodiploids exhibit a $\mathrm{Str}^{\mathrm{s}}$ phenotype due to the presence of the dominant wildtype $r p s 12$ gene inserted at the $p s b A I$ locus (Fig. 2b, top), removal of the wild-type rps12 gene from the merodiploids should restore the $\operatorname{Str}^{\mathrm{r}}$ phenotype inherent from the rps12-R43 allele. Gene replacement at the $p s b A I$ locus was initiated by introducing appropriate template DNAs bearing terminal regions of homology with $p s b A I$ $5^{\prime}$ and $3^{\prime}$ flanking sequences, thus inducing homologous recombination via double crossing-over (Fig. 2b, bottom). In principle, such a recombinant with a successful gene replacement can be detected by their $\operatorname{Str}^{r}$ as well as kanamycin-sensitive $\left(\mathrm{Km}^{\mathrm{s}}\right)$ phenotype because of the simultaneous elimination of the kan gene (Fig. 2c). On the other hand, spontaneous gene conversion of the 
Table 4. Gene replacement in rps12 merodiploids by transformation with template plasmids

\begin{tabular}{|c|c|c|c|c|c|}
\hline $\begin{array}{l}\text { Plasmid (amount } \\
\text { used)* }\end{array}$ & $\begin{array}{l}\text { Recipient } \\
\text { strain }\end{array}$ & $\begin{array}{l}\text { Number of } \\
\text { Str }{ }^{r} \text { colonies }\end{array}$ & $\begin{array}{l}\text { Number of } \\
\mathrm{Km}^{\mathrm{r}} \text { colonies }\end{array}$ & $\begin{array}{c}\text { Frequency of } \mathrm{Str}^{\mathrm{r}} \\
\text { clones per } \mathrm{Km}^{\mathrm{r}} \\
\text { population } \dagger\end{array}$ & $\begin{array}{l}\text { Number of } \mathrm{Km}^{\mathrm{s}} \\
\text { transformants per } \mathrm{Str}^{\mathrm{r}} \\
\text { clone tested } \neq\end{array}$ \\
\hline pEXGFP $(1 \mu \mathrm{g})$ & \multirow[t]{4}{*}{ GRPS11 } & $1.54 \times 10^{4}$ & $1 \cdot 36 \times 10^{8}$ & $1 \cdot 1 \times 10^{-4}$ & $3 / 96$ \\
\hline $\begin{array}{c}\mathrm{pEXGFP}(2 \mu \mathrm{g}) / \\
E c o \mathrm{RI}+S p h \mathrm{I}\end{array}$ & & $1.38 \times 10^{4}$ & $1.20 \times 10^{8}$ & $1 \cdot 2 \times 10^{-4}$ & $0 / 96$ \\
\hline pEXE1 $(1 \mu \mathrm{g})$ & & $2 \cdot 40 \times 10^{4}$ & $1.85 \times 10^{8}$ & $1 \cdot 3 \times 10^{-4}$ & $0 / 96$ \\
\hline pEXE1 $(2 \mu \mathrm{g}) /$ Bam HI & & $2 \cdot 40 \times 10^{4}$ & $2 \cdot 59 \times 10^{8}$ & $9 \cdot 3 \times 10^{-5}$ & $0 / 96$ \\
\hline pEXGFP $(1 \mu \mathrm{g})$ & \multirow[t]{4}{*}{ GRPS21 } & $1.56 \times 10^{3}$ & $7 \cdot 32 \times 10^{8}$ & $2 \cdot 1 \times 10^{-6}$ & $3(1) / 96$ \\
\hline $\begin{array}{c}\mathrm{pEXGFP}(2 \mu \mathrm{g}) / \\
E c o \mathrm{RI}+S p h \mathrm{I}\end{array}$ & & $1.30 \times 10^{3}$ & $5 \cdot 26 \times 10^{7}$ & $2.5 \times 10^{-5}$ & $0 / 96$ \\
\hline pEXE1 $(1 \mu \mathrm{g})$ & & $4.97 \times 10^{3}$ & $2 \cdot 23 \times 10^{8}$ & $2 \cdot 2 \times 10^{-5}$ & $1(0) / 96$ \\
\hline pEXE1 (2g)/BamHI & & $3 \cdot 42 \times 10^{3}$ & $1.97 \times 10^{8}$ & $1.7 \times 10^{-5}$ & $0 / 96$ \\
\hline \multirow[t]{2}{*}{ pUC3032 $(0.5 \mu \mathrm{g})$} & GRPS11 & NA & NA & NA & $3 / 100$ \\
\hline & GRPS21 & NA & NA & NA & $16 / 100$ \\
\hline
\end{tabular}

* Plasmids were used as closed circular molecules or digested with restriction enzyme(s) prior to electroporation.

† Numbers represent single measurements.

$\ddagger \mathrm{Km}^{\mathrm{s}}$ phenotypes of 96 and 100 randomly picked $\mathrm{Str}^{\mathrm{r}}$ colonies were tested in liquid and solid BG-11 medium containing kanamycin, respectively. In the case of transformation of GRPS21, two and one $\operatorname{Str}^{\mathrm{r}} \mathrm{Km}^{\mathrm{s}}$ recombinants obtained by using pEXGFP and pEXE1, respectively, were heterogenotes segregating $\mathrm{Km}^{\mathrm{r}}$ cells in subcultures and were therefore subtracted, as shown by the numbers in parentheses.

NA, Not applicable because transformants were selected by $\mathrm{Cm}^{\mathrm{r}}$ phenotype, and then $\mathrm{Str}^{\mathrm{r}}$ clones from a plasmid-bearing transformant were recovered.

rps12 gene at the psbAI locus into the rps12-R43 allele will lead to $\operatorname{Str}^{\mathrm{r}}$ merodiploid cells that are still $\mathrm{Km}^{\mathrm{r}}$ (Fig. 2d). Thus, products of true gene replacement can be distinguished from those of gene conversion by their kanamycin phenotype among the $\operatorname{Str}^{\mathrm{r}}$ population.

At first, we employed plasmids unable to replicate in cyanobacteria as template DNAs to replace the $p s b A I$ gene with foreign sequences. One of the template plasmids, pEXGFP, was used to precisely replace the psbAI ORF with the $g f p$ ORF encoding a green fluorescent protein (GFPuv), whereas pEXE1 bearing the $p s b A I \Delta \mathrm{ORF}$ gene was employed to introduce a precise deletion of the $p s b A I$ ORF. Two Str ${ }^{\mathrm{s}}$ merodiploid strains, GRPS11 and GRPS21 (Tables 1 and 3), were selected and electroporated with pEXGFP or pEXE1. The results of four independent experiments showed that the frequencies of $\operatorname{Str}^{\mathrm{r}} \mathrm{Km}^{\mathrm{s}}$ recombinants were low, reaching a maximum of only $3 / 96$ using $1 \mu \mathrm{g}$ intact plasmid (Table 4, last column). No $\operatorname{Str}^{\mathrm{r}} \mathrm{Km}^{\mathrm{s}}$ recombinant was detected among $96 \operatorname{Str}^{\mathrm{r}}$ colonies using $2 \mu \mathrm{g}$ linearized plasmid.

The seven $\operatorname{Str}^{\mathrm{r}} \mathrm{Km}^{\mathrm{s}}$ recombinant clones obtained above were analysed for their chromosomal structure at the psbAI locus by PCR using primers that amplify DNA segments from outside the psbAI ORF (Fig. 3). Six Str ${ }^{\mathrm{r}}$ $\mathrm{Km}^{\mathrm{s}}$ recombinants obtained by using pEXGFP (Fig. 3, lanes 4-9) gave rise to $1.3 \mathrm{~kb}$ DNA bands corresponding to the $p s b A I:: g f p \mathrm{ORF}$, while a $0.6 \mathrm{~kb}$ band corresponding to the deletion of psbAI ORF was amplified from one $\operatorname{Str}^{\mathrm{r}} \mathrm{Km}^{\mathrm{s}}$ recombinant obtained by using
pEXE1 (Fig. 3, lane 10). These PCR fragment sizes are in good agreement with the expected gene replacement products at their psbAI loci. When these $\operatorname{Str}^{\mathrm{r}} \mathrm{Km}^{\mathrm{s}}$ recombinants with potential gene replacement were analysed further by Southern hybridization, the rps 12 or $r p s 12$ ORF insertions at the $p s b A I$ locus were eliminated in seven recombinants and replaced by $g f p$ ORF fragments in six recombinants (Fig. 4).

\section{Heterogenote formation in the psbAl locus}

Although the above results of PCR and Southern hybridization showed that the gene replacement was feasible utilizing the rps12 merodiploid strains and the appropriate template plasmids, a possibility still remained that the $p s b A I$ locus might be heterogeneous in some of the $\operatorname{Str}^{r} \mathrm{Km}^{\mathrm{s}}$ transformants. Careful inspection of Southern hybridization results disclosed that traces of hybridizing bands were present at 4.4 or $4.2 \mathrm{~kb}$ positions in a few transformants (e.g. Fig. 4a, lanes 10 and 11). Should the kan gene remain inserted at a fraction of $p s b A I$ loci, they would revive some $\mathrm{Km}^{\mathrm{r}}$ cells. Indeed, three out of seven recombinants described above (Table 4) segregated a small number of growing colonies on BG-11 medium containing kanamycin after prolonged incubation. Consequently, these three recombinants were regarded as heterogenotes at the $p s b A I$ locus containing both the replaced ( $g f p$ ORF or $p s b$ $A I \Delta \mathrm{ORF})$ and unreplaced (rps12ORF-kan) insertions. PCR tests also disclosed the presence of the kan gene in their chromosomal DNAs (data not shown). In con- 


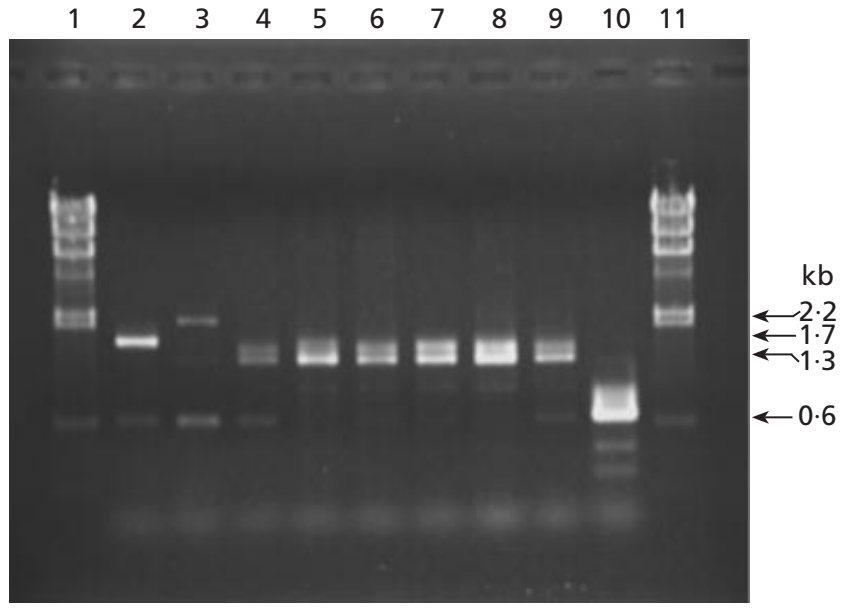

Fig. 3. $P C R$ analysis of cyanobacterial recombinants with potential gene replacement at their psbAl loci. Chromosomal DNAs from $\mathrm{Str}^{r} \mathrm{Km}^{\mathrm{s}}$ recombinants obtained from rps12 merodiploid strains were analysed by PCR using primers 13 and 14 , which anneal to the $5^{\prime}$ and $3^{\prime}$ non-coding regions of the psbAl gene, respectively. Amplified DNAs were subjected to agarose gel electrophoresis and visualized by ethidium bromide staining. Lanes: 1 and 11 , HindIII-cut $\lambda$ DNA marker; 2 , GRPS1; 3, GRPS21; 4-6, $\operatorname{Str}^{\mathrm{r}} \mathrm{Km}^{\mathrm{s}}$ transformants from GRPS11 obtained with pEXGFP; 7-9, $\mathrm{Str}^{\mathrm{r}} \mathrm{Km}^{\mathrm{s}}$ transformants from GRPS21 obtained with pEXGFP; $10, \mathrm{Str}^{\mathrm{r}} \mathrm{Km}^{\mathrm{s}}$ transformant from GRPS21 obtained with pEXE1. In lanes 4-9, $1.5 \mathrm{~kb}$ bands of unknown origin were seen in addition to the expected $1.3 \mathrm{~kb}$ bands. Sizes of the amplified DNA bands are indicated on the right.

clusion, transformation of the rps12 merodiploid strains with non-replicating template plasmids finally resulted in four $\operatorname{Str}^{\mathrm{r}} \mathrm{Km}^{\mathrm{s}}$ homogenote recombinants, in which all copies of the $p s b A I$ ORF were replaced by the $g f p$ ORF.

\section{Functional expression of the gfp ORF integrated at the psbAl locus}

To investigate whether or not the gene replacement at the $p s b A I$ locus led to expression of the $g f p$ ORF under the control of the constitutive psbAI promoter, we analysed GFPuv protein in cyanobacterial cells under a fluorescence microscope. GFPuv absorbs ultraviolet light at 360-400 nm, and emits green fluorescence with a maximum at $509 \mathrm{~nm}$ (Crameri et al., 1996). Since cyanobacterial chlorophylls also absorb ultraviolet light, and emit red fluorescence with a maximum at $668 \mathrm{~nm}$, only emission in the range $510-550 \mathrm{~nm}$ was visualized through an absorption filter. Moreover, the intracellularly emitted light might have been quenched by various absorbing pigment molecules. Nonetheless, the above cyanobacterial recombinants with a $p s b A I:: g f p$ ORF genotype, as well as a control strain GLC1 (Table 1) with a psbAI::gfpORF-nak genotype did emit the dim fluorescence which was absent in the parental GRPS1 strain (data not shown). We also detected the expression of green fluorescent protein by Western blotting of cell-free extracts from the recombinant cyanobacterial strains (data not shown). These data clearly demonstrated that the $g f p$ ORF inserted at (a)

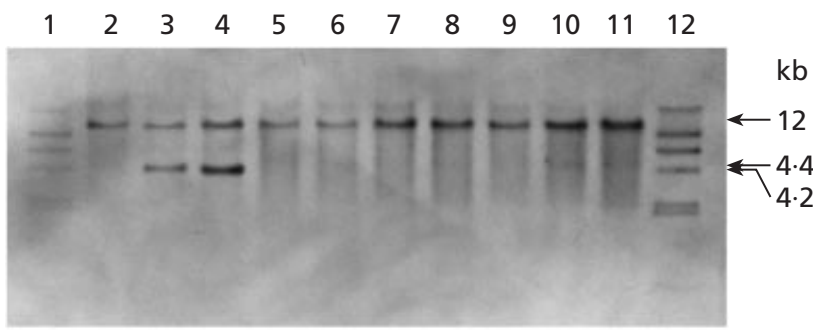

(b)

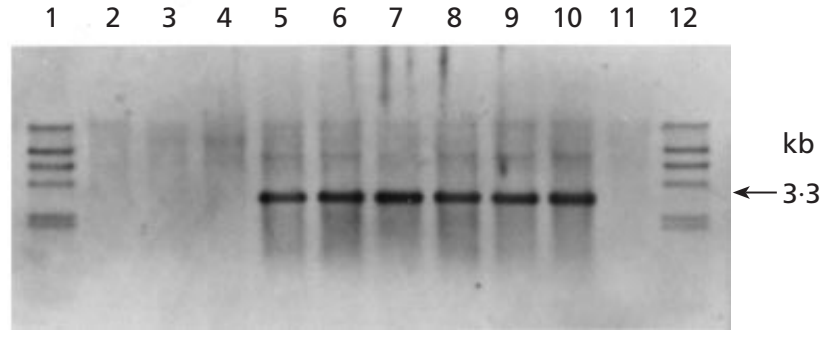

Fig. 4. Genomic Southern hybridization of gene replacement recombinants obtained with non-replicating template plasmids. Lanes 2-11 contain $5 \mu \mathrm{g}$ Scal-digested chromosomal DNA. Hybridization was carried out with $5 \times \mathrm{SSC}$ at $65^{\circ} \mathrm{C}$ using either (a) an rps12 ORF probe, or (b) a gfp ORF probe. Lanes: 1 and 12, digoxigenin-labelled, Hindlll-cut $\lambda$ DNA marker; 2, GRPS1; 3, GRPS11; 4, GRPS21; 5-7, potential psbAl::gfpORF gene replacement recombinants from GRPS11; 8-10, potential psbAl::gfpORF gene replacement recombinants from GRPS21; 11 , potential psbAISORF recombinant from GRPS21. Sizes of hybridizing bands are indicated on the right. The 4.4 and $4.2 \mathrm{~kb}$ bands in lanes 3 and 4 correspond to psbAl::rps12 and psbAl::rps12ORF fragments, respectively.

the $p s b A I$ locus is intact and functional after gene replacement.

\section{Transformation of rps 12 merodiploids with replicating template plasmids}

The frequency at which gene replacement products are established from rps12 merodiploids depends upon the availability of template DNA within the cyanobacterial cells. When a template plasmid replicates after incorporation into a cell to supply multiple copies of templates, then the probability of homologous recombination between the plasmid DNA and the chromosomal DNA should be elevated as compared with a nonreplicating template plasmid which is diluted out during cell propagation. To test the above hypothesis, a pUC303-derived plasmid, pUC3032 (Table 1), carrying the $p s b A I \Delta \mathrm{ORF}$ gene and cyanobacterial replication machinery was constructed. pUC3032 is devoid of the plasmid-borne $\mathrm{Sm}^{\mathrm{r}}$ gene but carries the $\mathrm{Cm}^{\mathrm{r}}$ gene and rep $A B$ genes necessary for autonomous replication in PCC 7942 or its cognate strains lacking endogenous pUH24 (van der Plas et al., 1992). This plasmid was used to introduce a deletion of the $p s b A I$ gene ORF by gene replacement in the rps12 merodiploid strains.

As shown in the last row of Table 4, transformation of strains GRPS11 and GRPS21 using pUC3032 resulted in 


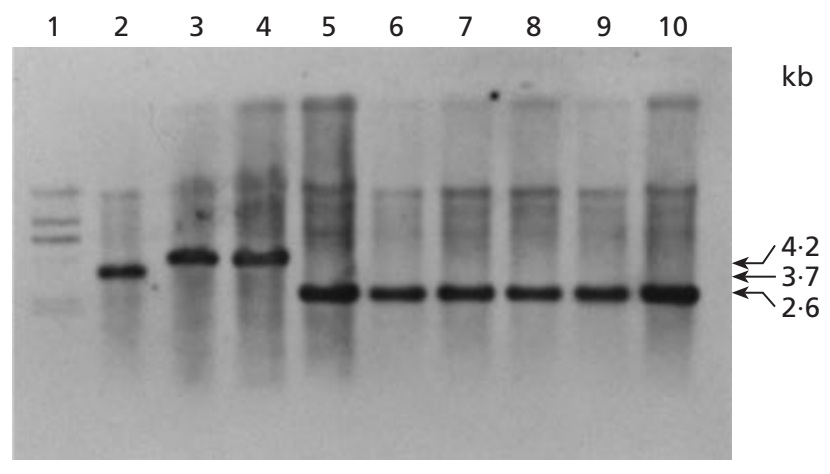

Fig. 5. Southern hybridization of recombinant cyanobacteria from rps12 merodiploids obtained after transformation with replicating template plasmid. All the chromosomal DNAs $(5 \mu \mathrm{g})$ were cut by Scal. A digoxigenin-labelled $625 \mathrm{bp}$ fragment consisting of joined psbAl $5^{\prime}$ and $p s b A / 3^{\prime}$ non-coding sequences was prepared by PCR with pEXE1 as a template using primers 13 and 14 , and was used as a probe. Hybridization was carried out in $5 \times$ SSC at $65{ }^{\circ} \mathrm{C}$. Lanes: 1, digoxigenin-labelled, Hindlllcut $\lambda$ DNA marker; 2 , GRPS1; 3, GRPS11; 4, GRPS21; 5-7, potential psbAI $\triangle$ ORF recombinants from GRPS11; 8-10, potential $p s b A I \triangle O R F$ recombinants from GRPS21. Sizes of hybridizing DNA bands are shown on the right.

three and sixteen recombinants exhibiting the $\mathrm{Cm}^{\mathrm{r}} \mathrm{Str}^{\mathrm{r}}$ $\mathrm{Km}^{\mathrm{s}}$ phenotype from GRPS11 and GRPS21, respectively, among $100 \operatorname{Str}^{\mathrm{r}}$ clones tested. These recombinants were homogenotes as judged from their inability to grow on BG-11 medium containing kanamycin. The apparent frequencies of $\mathrm{Km}^{\mathrm{s}}$ recombinants among $\mathrm{Str}^{\mathrm{r}}$ clones $(3$ and $16 \%$ ) using a replicating plasmid were improved in comparison with those (less than $3 \%$ ) using nonreplicating plasmids.

Three clones of each $\mathrm{Cm}^{\mathrm{r}} \mathrm{Str}^{\mathrm{r}} \mathrm{Km}^{\mathrm{s}}$ recombinant from GRPS11 and GRPS21 were cured for their pUC3032 (see Methods), and one chloramphenicol-sensitive $\left(\mathrm{Cm}^{\mathrm{s}}\right)$ strain was recovered from each clone. When these $\mathrm{Cm}^{\mathrm{s}}$ $\mathrm{Str}^{\mathrm{r}} \mathrm{Km}^{\mathrm{s}}$ recombinant strains were analysed by PCR using the same primers as in Fig. 3, DNA fragments of an expected size $(0.6 \mathrm{~kb})$ were amplified (data not shown). Southern hybridization of ScaI-digested chromosomal DNA from the above six cured strains using a probe specific for the $p s b A I 5^{\prime}$ and $3^{\prime}$ non-coding sequences detected the same $2.6 \mathrm{~kb}$ bands corresponding to a $1.08 \mathrm{~kb}$ deletion of the psbAI gene ORF, as compared with a $3.7 \mathrm{~kb}$ band in GRPS1 and $4.4 / 4.2 \mathrm{~kb}$ bands in strains GRPS11 and GRPS21, depending on the insertions (rps12-nak or rps12ORF-kan) which they carry at the $p s b A I$ locus (Fig. 5). This result provides direct evidence that the $p s b A I \Delta \mathrm{ORF}$ gene is transferred from a replicating plasmid to the chromosomal psbAI locus with a concomitant loss of rps12 and kan genes at the same locus.

\section{DISCUSSION}

Since the elucidation of the lethal effect of streptomycin on $30 \mathrm{~S}$ ribosomes as causing erroneous protein synthesis (Gorini, 1974), mutational sites in $\operatorname{Str}^{\mathrm{r}}$ mutants of various organisms have been assigned to either the $30 \mathrm{~S}$ ribosomal subunit protein S12 (Funatsu \& Wittmann, 1972; Liu et al., 1989; Timms et al., 1992; Finken et al., 1993) or 16S rRNA (Montandon et al., 1985; Melancon et al., 1988; Powers \& Noller, 1991; Finken et al., 1993). The same amino acid substitutions as found here have been reported in some $\operatorname{Str}^{\mathrm{r}}$ mutant S12 proteins from $E$. coli (Funatsu \& Wittmann, 1972; Timms et al., 1992) and Mycobacterium tuberculosis (Finken et al., 1993) at Lys-43 as well as Lys-88, both of which are phylogenetically conserved. The small size and well-defined $\operatorname{Str}^{\mathrm{r}}$ mutational sites of the $r p s 12$ gene imply a universal applicability of rps12-mediated gene replacement in other organisms amenable to transformation.

The dominant nature of the wild-type rps12 gene over the rps12-R43 allele was demonstrated unambiguously by the $\mathrm{Str}^{\mathrm{S}}$ phenotype of merodiploid strains bearing the rps12-R43 allele and the rps 12 gene inserted at the $p s b A I$ locus. The difference in the ability of promoters to express the ectopic rps12 gene, i.e. the natural rps12 promoter or the $p s b A I$ promoter, did not influence the apparent $\operatorname{Str}^{\mathrm{s}}$ phenotype of the merodiploids, although the $p s b A I$ promoter seemed stronger than the rps12 promoter. However, rps12 gene and rps12 ORF sequences have different tendencies to suffer gene conversion. Thus, the spontaneous segregation rate of $\operatorname{Str}^{\mathrm{r}}$ progeny was about seven times higher in the GRPS11 merodiploid carrying the rps12 gene than in the GRPS21 merodiploid carrying the rps12 ORF (see Table 4, fifth column). Although its basis is not known exactly, this difference in gene conversion frequencies might arise from a site-specific recombination at a highly iterated palindromic sequence (HIP1), 5'-GCGATCGC-3', which has been found in many cyanobacteria (Robinson et al., 1995, 1997; Akiyama et al., 1998) and is present once in the promoter region of the $579 \mathrm{bp}$ rps 12 gene but absent from the $375 \mathrm{bp}$ rps12 ORF. We therefore postulate that rps12 merodiploids would be a good experimental system to study mechanistic details of intrachromosomal gene conversion in cyanobacteria.

The present study established a novel technique utilizing a dominant $\operatorname{Str}^{\mathrm{S}}$ rps12 gene to replace any non-essential chromosomal sequences in cyanobacteria with desired insertions, substitutions or deletions, yet generating the final mutants free from foreign drug resistance markers. Essentially, this method consists of an elimination of the chromosomally integrated rps12 gene via homologous recombination with externally added template DNA. A similar strategy was employed previously to select plasmid-to-chromosome gene replacement in E. coli recD rpsL (str) mutants (Russell \& Dahlquist, 1989). In E. coli, however, a strong exonucleolytic activity conferred by the recBCD gene product makes linear DNA fragments impractical for use as template DNA, and, therefore, it is still mandatory to use a recBCD-deficient mutant for efficient gene replacement (Murphy, 1998). Although cyanobacteria do not seem to degrade linear DNA so extensively, linearized template DNAs were much less effective than circular DNAs for gene replacement. Taking it for granted that recA-mediated 
homologous recombination requires sufficient length of sequences flanking the sequence to be integrated, we employed template plasmids carrying the $p s b A I 5^{\prime}$ and 3' non-coding sequences extending to more than $500 \mathrm{bp}$. Whether or not a specific sequence such as HIP1 is required for high frequency of recombination is not known, although both psbAI $5^{\prime}$ and $3^{\prime}$ flanking sequences used here contain at least one HIP1 site (unpublished results).

Compared with the haploid genome of E. coli, the polyploid nature of the cyanobacterial genome poses an additional difficulty in isolating homogenote recombinants. Available data indicate that the mean copy number of chromosomes per cell in Synechococcus spp. PCC 6301 and PCC 7942 is four to six, depending on growth rate and temperature (Binder \& Chisholm, 1990). Accordingly, several rounds of successive replacements at $p s b A I$ loci in a polyploid genome should be necessary to establish homogenote recombinants. Considering the transient maintenance of non-replicating plasmids after incorporation into the cell, it is somewhat surprising that gene replacement was achieved at a frequency up to $3 \%$ of the $\operatorname{Str}^{\mathrm{r}}$ progeny using a circular form of a non-replicating plasmid. This frequency corresponds to about $3 \times 10^{-6}$ per cell, a value not impractical to screen for recombinants among $10^{8}$ cells. When the template plasmids replicate, gene replacement was induced via three steps: first, transformation with the $\mathrm{Cm}^{\mathrm{r}}$ plasmid; second, induction of recombination to give $\operatorname{Str}^{r} \mathrm{Km}^{\mathrm{s}}$ progeny ; and finally, curing of the plasmid. This procedure has an advantage in the availability of multiple copies of template plasmids in all transformant cells, resulting in an increased frequency of gene replacement of up to $16 \%$ among survivors. Although the curing of the plasmid is an added labour, most of the shuttle vector plasmids currently available in cyanobacteria are unstable and therefore could be removed relatively easily.

The ease with which gene replacements were screened is an urgent requirement for routine work with mutant constructions. So far, a conditional lethal $s a c B$ gene encoding levansucrase can cause death of host cells of Gram-negative bacteria on sucrose-containing media (Gay et al., 1985), and has been utilized as a tool for construction of gene replacement mutants in a plant pathogen, Erwinia chrysanthemi (Ried \& Collmer, 1987), and a filamentous cyanobacterium, Anabaena sp. PCC 7120 (Cai \& Wolk, 1990). The sacB gene, however, suffers inactivation through spontaneous mutations, leading to false recombinants. In the rps12-mediated gene replacement, segregation of false Str ${ }^{r}$ recombinants from the rps12/rps12-R43 merodiploids by gene conversion is unavoidable when using the $100 \%$ homologous rps12 gene in the $r e c A^{+}$background. However, we expect to suppress the gene conversion frequency in merodiploids by using an rps12 gene homologue such as the E. coli rpsL gene or by using a mutant strain deficient in an as yet unidentified gene conversion system. There is a tenable experimental basis for the heterologous expression of S12 proteins in different hosts (Liu et al.,
1989). We are at present exploring the feasibility of employing heterologous rps12 genes to obtain cyanobacterial merodiploids with a stable $\operatorname{Str}^{\mathrm{s}}$ phenotype.

\section{ACKNOWLEDGEMENTS}

This work was supported by a grant-in-aid for scientific research from the Japan Society for the Promotion of Science (no. 11660330). We are grateful to Dr N. Gunge for his valuable comments on this work. The authors thank $M$. Yamashita, K. Yamagata and M. Koga for their help in construction of plasmids and strains.

\section{REFERENCES}

Akiyama, H., Kanai, S., Hirano, M. \& Miyasaka, H. (1998). A novel plasmid recombination mechanism of the marine cyanobacterium Synechococcus sp. PCC7002. DNA Res 5, 327-334.

Binder, B. J. \& Chisholm, S. W. (1990). Relationship between DNA cycle and growth rate in Synechococcus sp. strain PCC 6301. J Bacteriol 172, 2313-2319.

Bustos, S. A. \& Golden, S. S. (1992). Light-regulated expression of the $p s b D$ gene family in Synechococcus sp. strain PCC 7942: evidence for the role of duplicated $p s b D$ genes in cyanobacteria. Mol Gen Genet 232, 221-230.

Cai, Y. \& Wolk, C. P. (1990). Use of a conditionally lethal gene in Anabaena sp. strain PCC 7120 to select for double recombinants and to entrap insertion sequences. J Bacteriol 172, 3138-3145.

Chauvat, F., De Vries, L., Van der Ende, A. \& Van Arkel, G. A. (1986). A host-vector system for gene cloning in the cyanobacterium Synechocystis PCC 6803. Mol Gen Genet 204, 185-191.

Crameri, A., Whitehorn, E. A., Tate, E. \& Stemmer, W. P. C. (1996). Improved green fluorescent protein by molecular evolution using DNA shuffling. Nature Biotechnol 14, 315-319.

Dean, D. (1981). A plasmid cloning vector for the direct selection of strains carrying recombinant plasmids. Gene 15, 99-102.

Finken, M., Kirschner, P., Meier, A., Wrede, A. \& Böttger, E. C. (1993). Molecular basis of streptomycin resistance in $\mathrm{Myco-}$ bacterium tuberculosis: alterations of the ribosomal protein S12 and point mutations within a functional $16 \mathrm{~S}$ ribosomal RNA pseudoknot. Mol Microbiol 9, 1239-1246.

Funatsu, G. \& Wittmann, H. G. (1972). Ribosomal proteins. XXXIII. Location of amino-acid replacements in protein S12 isolated from Escherichia coli mutants resistant to streptomycin. J Mol Biol 68, 547-550.

Gay, P., Le Coq, D., Steinmetz, M., Berkelman, T. \& Kado, C. I. (1985). Positive selection procedure for entrapment of insertion sequence elements in gram-negative bacteria. J Bacteriol 164, 918-921.

Geerts, D., Bovy, A., de Vrieze, G., Borrias, M. \& Weisbeek, P. (1995). Inducible expression of heterologous genes targeted to a chromosomal platform in the cyanobacterium Synechococcus sp. PCC 7942. Microbiology 141, 831-841.

Ghassemian, M. \& Straus, N. A. (1996). Fur regulates the expression of iron-stress genes in the cyanobacterium Synechococcus sp. strain PCC 7942. Microbiology 142, 1469-1476.

Golden, S. S., Brusslan, J. \& Haselkorn, R. (1986). Expression of a family of $p s b A$ genes encoding a photosystem II polypeptide in the cyanobacterium Anacystis nidulans R2. EMBO $J$ 5, 2789-2798.

Golden, S. S., Nalty, M. S. \& Cho, D. S. (1989). Genetic relationship of two highly studied Synechococcus strains designated Anacystis nidulans. J Bacteriol 171, 24-29. 
Gondo, Y., Shioyama, Y., Nakao, K. \& Katsuki, M. (1996). A novel positive detection system of in vivo mutations in rpsL (strA) transgenic mice. Mutat Res 360, 1-14.

Gorini, L. (1974). Streptomycin and misreading of the genetic code. In Ribosomes, pp. 791-803. Edited by M. Nomura, A. Tissieres \& P. Lengyel. Cold Spring Harbor, NY: Cold Spring Harbor Laboratory.

Hashimoto-Gotoh, T., Tsujimura, A., Kuriyama, K. \& Matsuda, S. (1993). Construction and characterization of new host-vector systems for the enforcement-cloning method. Gene 137, 211-216.

Kuhlemeier, C. J., Thomas, A. A. M., Van der Ende, A., Van Leen, R. W., Borrias, W. E., Van den Hondel, C. A. M. J. J. \& Van Arkel, G. A. (1983). A host-vector system for gene cloning in the cyanobacterium Anacystis nidulans R2. Plasmid 10, 156-163.

Lederberg, J. (1951). Streptomycin resistance: a genetically recessive mutation. J Bacteriol 61, 549-550.

Liu, X.-Q., Gillham, N. W. \& Boynton, J. E. (1989). Chloroplast ribosomal protein gene rps12 of Chlamydomonas reinhardtii. Wild-type sequence, mutation to streptomycin resistance and dependence, and function in Escherichia coli. J Biol Chem 264, 16100-16108.

Melancon, P., Lemieux, C. \& Brakier-Gingras, L. (1988). A mutation in the 530 loop of Escherichia coli $16 \mathrm{~S}$ ribosomal RNA causes resistance to streptomycin. Nucleic Acids Res 16, 9631-9639.

Meng, B.-Y., Shinozaki, K. \& Sugiura, M. (1989). Genes for the ribosomal proteins $\mathrm{S} 12$ and S7 and elongation factors EF-G and EF-Tu of the cyanobacterium, Anacystis nidulans: structural homology between $16 \mathrm{~S}$ rRNA and S7 mRNA. Mol Gen Genet 216, 25-30.

Montandon, P.-E., Nicolas, P., Schürmann, P. \& Stutz, E. (1985). Streptomycin-resistance of Euglena gracilis chloroplasts: identification of a point mutation in the $16 \mathrm{~S}$ rRNA gene in an invariant position. Nucleic Acids Res 13, 4299-4310.

Murphy, K. C. (1998). Use of bacteriophage recombination functions to promote gene replacement in Escherichia coli. J Bacteriol 180, 2063-2071.

Murphy, R. C., Gasparich, G. E., Bryant, D. A. \& Porter, R. D. (1990). Nucleotide sequence and further characterization of the Synechococcus sp. strain PCC 7002 recA gene: complementation of a cyanobacterial recA mutation by the Escherichia coli recA gene. J Bacteriol 172, 967-976.

Nixon, P. J. \& Diner, B. A. (1994). Analysis of water-oxidation mutants constructed in the cyanobacterium Synechocystis sp. PCC 6803. Biochem Soc Trans 22, 338-343.

Pakrasi, H. B. (1995). Genetic analysis of the form and function of photosystem I and photosystem II. Annu Rev Genetics 29, 755-776.

Powers, T. \& Noller, H. F. (1991). A functional pseudoknot in $16 \mathrm{~S}$ ribosomal RNA. EMBO J 10, 2203-2214.
Ried, J. L. \& Collmer, A. (1987). An $n p t I-s a c B-s a c R$ cartridge for constructing directed, unmarked mutations in gram-negative bacteria by marker exchange-eviction mutagenesis. Gene 57, 239-246.

Robinson, N. J., Robinson, P. J., Gupta, A., Bleasby, A. J., Whitton, B. A. \& Morby, A. P. (1995). Singular overrepresentation of an octameric palindrome, HIP1, in DNA from many cyanobacteria. Nucleic Acids Res 23, 729-735.

Robinson, P. J., Cranenburgh, R. M., Head, I. M. \& Robinson, N. J. (1997). HIP1 propagates in cyanobacterial DNA via nucleotide substitutions but promotes excision at similar frequencies in Escherichia coli and Synechococcus PCC 7942. Mol Microbiol 24, 181-189.

Russell, C. B. \& Dahlquist, F. W. (1989). Exchange of chromosomal and plasmid alleles in Escherichia coli by selection for loss of a dominant antibiotic sensitivity marker. J Bacteriol 171, 2614-2618.

Saiki, R. K., Gelfand, D. H., Stoffel, S., Scharf, S. J., Higuchi, R., Horn, G. T., Mullis, K. B. \& Erlich, H. A. (1987). Primer-directed enzymatic amplification of DNA with a thermostable DNA polymerase. Science 239, 487-491.

Sakai, M., Ogawa, T., Matsuoka, M. \& Fukuda, H. (1997). Photosynthetic conversion of carbon dioxide to ethylene by the recombinant cyanobacterium, Synechococcus sp. PCC 7942, which harbors a gene for the ethylene-forming enzyme of Pseudomonas syringae. J Ferment Bioeng 84, 434-443.

Sambrook, J., Fritsch, E. F. \& Maniatis, T. (1989). Molecular Cloning: a Laboratory Manual, 2nd edn. Cold Spring Harbor, NY : Cold Spring Harbor Laboratory.

Timms, A. R., Steingrimsdottir, H., Lehmann, A. R. \& Bridges, B. A. (1992). Mutant sequences in the rpsL gene of Escherichia coli $\mathrm{B} / \mathrm{r}$ : mechanistic implications for spontaneous and ultraviolet light mutagenesis. Mol Gen Genet 232, 89-96.

Triglia, T., Peterson, M. G. \& Kemp, D. J. (1988). A procedure for in vitro amplification of DNA segments that lie outside the boundaries of known sequences. Nucleic Acids Res 16, 8186.

Van der Plas, J., Oosterhoff-Teertstra, R., Borrias, M. \& Weisbeek, P. (1992). Identification of replication and stability functions in the complete nucleotide sequence of plasmid pUH24 from the cyanobacterium Synechococcus sp. PCC 7942. Mol Microbiol 6, 653-664.

Williams, J. G. K. (1988). Construction of specific mutations in photosystem II photosynthetic reaction center by genetic engineering methods in Synechocystis 6803. Methods Enzymol 167, 766-778.

Received 13 November 2000; revised 20 March 2001; accepted 4 April 2001. 